\title{
Az Egyedüli Kapcsolattartási Pont és a Közös Kapcsolattartási Szolgálati Hely által foganatosított információcserét befolyásoló környezeti tényezők ${ }^{1}$
}

\author{
Environments influencing the cross-border information \\ exchange of the SPOC and PCCC
}

\begin{abstract}
Absztrakt
A határon átnyúló büncselekmények, a növekvő hibrid biztonsági kockázat megköveteli a hatékony nemzetközi rendőri együttmüködést és információcserét. Válaszként előbbi igényre számos csatorna jött létre és folytat napjainkban határon átnyúló információcserét. A két legismertebb az Egyedüli Kapcsolattartási Pont (SPOC), valamint a Közös Kapcsolattartási Szolgálati Hely (KSZH). Ezen kutatás célja, hogy betekintést nyújtson az olvasónak a határon átnyúló rendészeti információcsere világába, feltárja a folyamatot hátráltató, illetve támogató tényezőket, valamint a két csatorna müködésében rejlő hasonlóságokat, különbségeket és lehetőségeket. A szerző ezt a célt a témában fellelhető releváns kutatások, valamint az általa végzett kvalitatív kutatás eredményeinek ismertetésével, valamint ajánlások megfogalmazásával kívánja elérni.
\end{abstract}

Kulcsszavak: nemzetközi együttmúködés, határon átnyúló információcsere, SPOC, KSZH, rendvédelem

\begin{abstract}
Cross-border criminality, emerging hybrid security threats demand efficient cross-border police cooperation and information exchange. To answer this need, various communication channels have been established to facilitate trans-border
\end{abstract}

1 A tanulmány a Frontex támogatásával készült. 
law-enforcement information exchange. The aim of this paper is to introduce the supporting and hindering factors of the two, most commonly used police information exchange channels, namely the Single Point of Contact (SPOC) and the Police and Customs Cooperation Centre (PCCC). The author tried to achieve this goal by introducing the relevant scientific theories and using them as a starting point for a qualitative study. The subsequent desk research and indepth interviews helped the researcher to describe the current information exchange process, the hindering and supporting factors, the characteristics and main differences of the SPOC and the PCCC information exchange processes.

Keywords: international cooperation, information exchange, SPOC, PCCC, law enforcement

\section{Bevezetés}

A határon átnyúló rendőri együttmüködés és információcsere talán sosem bírt olyan fontossággal, mint napjainkban, mikor a súlyosabb büncselekmények jelentős része, úgymint a terrorizmus, szervezett bünözés stb. elveszítette nemzeti jellegét, már nemzetközi méreteket öltött (Kovács, 2015, 115.). Nem véletlen tehát, hogy ezen információcsere megkönnyítése és hatékonyabbá tétele érdekében számos csatorna került kiépítésre és van jelenleg is használatban. Napjainkban a két legfontosabb és leggyakrabban használt csatorna az Egyedüli Kapcsolattartási Pont (Single Point of Contact - SPOC), valamint a Közös Kapcsolattartási Szolgálati Hely (KSZH). Számos tényező - többek között az irányadó jogszabályok, a személyes preferenciák, a megkeresés tárgya, komplexitása és sürgőssége - befolyásolja a csatornaválasztást, a gyakorlat azonban „nem egységes sem az EU-n belül, de még egy adott tagországban sem" (Doherty et al., 2015, 6.). Az egységes és egyértelmủ szabályozás, valamint gyakorlat hiánya gyakran zavarodottságot okoz és csökkenti az információcsere hatékonyságát, esetenként teljesen blokkolja azt. Mindez a gyakorlatban akként nyilvánul meg, hogy az információt igénylő személy, dacára a jogszabályoknak, irányelveknek, a számára ismertebb és kedvezőbb, többnyire a gyorsabbnak vélt csatornát veszi igénybe, illetve több csatornát használ egyszerre a gyors információszerzés érdekében. A fentieken kívül a hivatalos csatornák egyik komoly problémája számos esetben az információcsere lassúsága. Ezt támasztja alá a napjainkban gombamód szaporodó informális csatornák száma, melynek müködése többnyire személyes ismeretségen, közös kapcsolatrendszeren alapszik, és melyet előszeretettel használnak azon rendvédelmi dolgozók, akiknek munkájuk lelkiismeretes ellátásához 
gyors, perceken belüli információcsere szükséges. Személyes tapasztalatok azt is mutatják, hogy számos esetben azért nem kezdeményez a rendvédelmi dolgozó nemzetközi információcserét, mert tapasztalatai alapján tudja, hogy nem kap időben választ ahhoz, hogy a gyanús körülményröl helyben döntsön, mindez pedig súlyos kockázatot jelent mind az adott ország, mind pedig az Európai Unió biztonságára. Ezen kutatás célja, hogy betekintést nyújtson a határon átnyúló rendészeti információcsere világába, feltárja az ezt hátráltató, illetve támogató tényezőket és ezáltal segítséget nyújtson a döntéshozóknak és jogalkalmazóknak egy hatékony rendszer kidolgozásához, használatához. A kérdés megválaszolása érdekében ismertetjük a témában fellelhető releváns szakirodalmat, majd az elvégzett szekunder kutatás és mélyinterjúk elemzését követően ajánlásokat fogalmazunk meg a jogalkotóknak és jogalkalmazóknak.

\section{Szakirodalmi áttekintés}

\section{Az információcsere fogalma és szintjei}

Nemzetközi rendőri együttmüködés a Schengen térség létrejöttével vált létfontosságúvá az EU-n belül, amikor a belső határok megszünése által okozott biztonsági deficit kiküszöbölésére a Schengen Egyezmény több intézkedést, köztük a rendőri együttműködés fokozását írta elő a büncselekmények megelőzés és felderítése érdekében (Európai Unió, 1985, 39.). Az információcsere ezen rendőri együttműködés egyik formája, amikor is kettő vagy több részt vevő lényeges információt cserél formális vagy informális csatornákon keresztül (Cater, 2008, 3.). Az információcsere három szinten zajlik, ezáltal megkülönböztetünk személyek közötti, szervezeten belüli és szervezetek közötti cserét (Mausolf, 2010; Yang \& Maxwell, 2011, 171.). A hatékony nemzetközi (szervezetek közötti) információcsere alapvető feltétele a szerven belüli és a személyek közötti információcsere hatékonysága (Saloven et al., 2010, 83.). A hatékony információcsere feltétele ezeken kívül a megfelelő szervezeti, jogszabályi és technológiai környezet (Yang \& Maxwell, 2011, 169.), melyek többek között magukba foglalják a szervezeti struktúrát, kultúrát és értékeket, a bizalmat, vezetést-irányítást, jogi és IT eszközöket (Zhang \& Dawes, 2006).

\section{Az információcserét befolyásoló tényezök}

A szakirodalom egyetért abban, hogy a túlzottan centralizált és bürokratikus szervezeti struktúra akadályozza az információcserét, mivel a dolgozó 
önállósága csekély és minden döntéshozatal, így az információcsere is vezetöi jóváhagyást igényel (Kim \& Lee, 2006; Wheatley, 2006). A struktúra mellett jelentős befolyásoló hatással bír a szervezeti kultúra és a szervezeti értékek, mivel ezek kihatnak az egyéni, valamint a kollektív viselkedésre, ezáltal az információmegosztással kapcsolatos munkavégzésre (Constant et al., 1994). Az eltérő nemzeti rendszerek, kultúrák és munkamegosztás félreértésekhez és kommunikációs problémákhoz vezet, mely akadályozza az információcserét (Styczyńska \& Beaumont, 2017). A kölcsönösséget és a közös célokat szorgalmazó szervezeti kultúra azonban előmozdítja az információcserét (Bock et al., 2005), ahogy az erős személyes és szociális kapcsolatok is (Kim \& Lee, 2006). A bizalom alapvető kapcsolatépítő elem, mely jelentősen befolyásolja mind a szervezeten belüli, mind az azok közötti kooperációt és információcserét. A kutatások szerint, a bizalom nagysága és az információcserére való hajlam között pozitív összefüggés van (Goldenberg \& Dean, 2017, 85.), ami fellelhető a nemzetközi rendőri együttmüködés terén is, amely során a bizalom és a személyes kapcsolat egyike a legfontosabb kényszerítő erőknek (Hufnagel, 2016, 86.). Bstieler (2006) szerint ezen bizalmat növeli a megbízható, időbeni és adekvát információcsere, valamint a kölcsönös érdek, közös problémamegoldás és kiszámíthatóság. A bizalom mellett a várható viszonosság is fontos szerepet játszik a nemzetközi együttmüködés során (Keohane, 1986), és növeli mind a személyek, mind a szervezetek közötti információcserére való hajlamot - tartják a kutatók (Bock et al., 2005; Constant et al., 1994). A reciprocitás hatása megfigyelhető a rendészeti információcsere során is, a késedelmes válaszok és a viszonosság között a kutatók összefüggést találtak (Doherty et al., 2015, 29.). A menedzsment fajtája a következő tényező, mely kihatással van a szervezeti környezetre, ezáltal az információcserére (Resteigne \& Bogaert, 2017, 58.). Míg az autoriter vezetési stílus könnyen eltántoríthatja a beosztottat az információcserétől, addig a transzformációs vezetés bíztatja és támogatja az állományt ezen tevékenységben (Goldenberg \& Dean, 2017). Itt kell említést tennünk az ösztönzők szerepéről is. Az irányadó kutatások szerint ugyanis az információcserét ösztönző teljesítményértékelés és jutalmazás erősen motiváló, ezáltal növeli a csere hatékonyságát (Willem \& Buelens, 2007). Az általános, nem munkaspecifikus értékelési rendszer azonban hátrányosan befolyásolhatja a szervezetek közötti információcsere folyamatát (Zhang et al., 2005, 552.). Az irányadó jogszabályok és normák befolyásolják az egyének és a szervezet viselkedését, ezáltal a szervezetek közötti együttmüködést, derül ki az elméleti kitekintésből. A stabil és kiszámítható jogi környezet csökkenti az információcseréből adódó kockázatot és ezáltal fokozhatja az együttmüködést (Lane \& Bachmann, 1996; Zhang \& Dawes, 2006). A kutatók abban is egyetértenek, hogy az adatok védelmét 
és biztonságos kezelését támogató jogi háttér előmozdítja az információcserét (Gil-García \& Pardo, 2005). Emellett kiemelkedő fontosságú, hogy az irányadó normák egyértelmüek legyenek, ezáltal csökkenthetők az eltérő szervezeti kultúrákból és értékekből adódó félreértések száma (Zhang et al., 2005). A merev jogi háttér, az eltérő nemzeti adat- és titokvédelmi szabályok, valamint az EU instrumentumok nem egységes értelmezése azonban jelentősen akadályozzák az együttmüködést és az információcserét (Gil-García \& Pardo, 2005; Styczyńska \& Beaumont, 2017; Zhang et al., 2005). A szakirodalom egybehangzóan állítja, hogy a hatékony együttmüködés és információcsere foganatosításához elengedhetetlen a korszerú információtechnológiai (IT) háttér, mivel ez csökkenti a válaszadási időt és növeli a megküldött adat minőségét (Európai Bizottság, 2012, 12). Az IT rendszer akkor támogatja az információcserét, ha a különböző rendszerek homogének, valamint felhasználóbarátok és sok felhasználóval rendelkeznek (Kim \& Lee, 2006). A hatékonyságot csökkentheti a nagyszámú és nem átjárható adatbázisok száma, mivel ezek nehezítik a keresett információ kinyerését, duplikálást okoznak és növelik a válaszadásra szükséges időt (Európai Bizottság, 2004). Az IT rendszer megtervezésekor kiemelt figyelmet kell fordítani a szükséges hozzáférések biztosítására, valamint az adatok titkosítására és védelemére (Chau et al., 2002).

\section{Kutatásmódszertan}

A kutatás célja, hogy feltárja a SPOC és a KSZH által folytatott információcsere menetét, a hatékonyságot befolyásoló tényezőket, és hogy választ találjon arra, miként lehet a felmerülő akadályokat leküzdeni. A folyamat (esettanulmány) megértése érdekében kvalitatív kutatást végeztünk, mely szekunder kutatást és félig strukturált mélyinterjúk készítését, valamint elemzését foglalta magába (Yin, 2014, 1.). A szekunder kutatás során a szisztematikus kulcsszó keresés eredményeként számos dokumentum, norma és jelentés került kiválasztásra majd elemzésre azzal a céllal, hogy választ adjanak a kutatási kérdésekre (Saunders et al., 2008, 58.). A tartalomelemzésnél alkalmazott nyitott kódolás során lebontottuk, megvizsgáltuk, összehasonlítottuk, megcímkéztük és csoportosítottuk a kinyert adatokat (Bryman, 2012, 569.). Az elemzés eredménye végül összehasonlításra került az interjú során nyert adatokkal. Az interjúk megtervezésekor az irányított mintavétel (Bryman, 2012, 418.) technikáját használva választottunk ki három interjúalanyt, képviseltetve ezáltal mindkét csatornát, valamint a végfelhasználókat. Az interjúkérdések a szakirodalmi áttekintés és a szekunder kutatás eredményén alapultak, az interjúk Skype-on keresztül kerültek 
végrehajtásra, a kérdések és hozzájáruló nyilatkozatok előzetes megküldésével. Az interjúkról készült kivonat megküldésre került az interjúalanyoknak ellenőrzés céljából, csökkentve ezáltal a félreértés lehetőségét. A tematikus elemzés során a kutató által készített kódtáblázat segítségével kinyerésre kerültek a téma szempontjából jelentős információk (Bryman, 2012, 578.), melyek a szervezeti struktúra, menedzsment, hatékonyság, bizalom, jogi háttér, adatvédelem és adatokhoz való hozzáférés témakörei köré csoportosultak.

\section{A kvalitatív kutatás}

\section{Információcserét befolyásoló környezetek}

Az eltérő történelmi és szociokulturális háttér, oktatási rendszer, munkarendek, szokások és rendészeti struktúra eredményeként az EU tagállamok rendvédelmi berendezkedése és szerveinek szervezeti kultúrája jelentős eltérést mutat (Bayley, 1990). Mindezek jelentősen befolyásolják az információcserét, állapította meg az Európai Bizottság (2004), ezért kiemelt fontossággal bír a közös szervezeti kultúra létrehozása és az együttmüködést, valamint információcserét elősegítő egységes instrumentumok kidolgozása. A megkérdezett interjúalanyok általánosságban egyetértettek abban, hogy a szervezeti struktúra befolyásolja az információcsere folyamatát, a SPOC interjúalany kiegészítette ezt azzal, hogy „, a minőségi és gyors cserét jelentősen elösegíti a központositott irányitás, a homogén szervezet". Ha egy alapvető rendőri feladatot ellátó szerv müködik az országban - folytatta - az , megkönnyiti a szervezeten belüli kommunikációt, ezáltal az információhoz jutást, azonban le is lassithatja a folyamatot, mivel a rendörség egyszerre több feladatot lát el és elöfordulhat, hogy más feladatok élveznek prioritást".

Ami a szervezeti kultúrát illeti már nem minden válaszadó volt azonos véleményen, a KSZH-n és a végfelhasználóként dolgozó rendőr szerint a közös szervezeti kultúra fontos szerepet tölt be, a SPOC válaszadó azonban úgy vélte, hogy ennek ,nincsen jelentös hatása az információcserére, mivel munkánkat jogszabályok határozzák meg ezért a közös, illetve eltérö kultúra nem befolyásolja a feladatteljesitést". Valamennyi interjú alany egyetértett abban, hogy a parancsnoki támogatás, ezen belül is az ösztönzők és az elismerés kiemelt jelentőséggel bír. A feladathoz igazított teljesítményértékelési rendszer hiányáról számolt be valamennyi megkérdezett, a parancsnokok saját kezdeményezésre használnak nem intézményesített ösztönzőket. Ilyen általánosságban használt ösztönző a visszacsatolás rendszere, ami ,,megéri az eröfeszitést, mivel sokkal 
jobban motiválja az állományt, mint a pusztán adminisztrativ és hatástalan teljesitményértékelési rendszer" (KSZH válaszadó). Ezzel egyetértett a SPOC válaszadó is, a munkatársak motiváltsága és a hatékonyság jelentősen megnőtt a visszacsatolás bevezetését követően. A válaszadók elmondása szerint a parancsnokok többnyire nyitottak az újításra, azonban ez a támogatás csökken olyan alulról jövő kezdeményezések esetében, melyek nincsenek teljes összhangban az irányadó, többnyire adatvédelmi jogszabályokkal. Az információcserét folytatók között lévő személyes kapcsolat és bizalom gyorsíthatja az információcserét, értett egyet valamennyi interjúalany, ebben rejlik a KSZH „legnagyobb elönye, az információt cserélök egy fedél alatt dolgoznak, ami hozzájárul a jó személyes kapcsolatokhoz, ez pedig meggyorsitja az információcserét" - tette hozzá a KSZH válaszadó. A KSZH és a végfelhasználó szintén kiemelt fontosságúnak tartotta a reciprocitás és a közös érdek meglétét: „eltérő a hatékonyság és jóval nehezebb az együttmüködés akkor, ha a másik fél, például a liberális kábitószer szabályozásból kifolyólag nem érdekelt egy ügyben”. A SPOC munkatársa szerint azonban ,, ezek nem fontosak, munkánkat jogszabályok irják körül, az információcsere hatékonyan végbemegy a korábbi rossz tapasztalat ellenére, valamint közös érdek hiányában is”. Valamennyi válaszadó egyetértett abban, hogy a személyes kapcsolatok erősíthetők közös szolgálatellátással, munkaértekezletekkel és társasági rendezvényekkel, valamint „,csapatépitö tevékenységgel és konferenciákkal, amik segitenek a problémamegoldásban is" (SPOC válaszadó). Az interjúkból az is kiderül, hogy a KSZH állományának van több lehetösége a csapatépítésre: ,évente rendezünk csapatépitö tréningeket, havi rendszerességgel megünnepeljük a születésnapokat, nyugdijazásokat, ezek nem csak csapatépitésre szolgálnak, de segitenek megoldani a problémákat is" (KSZH válaszadó).

A jogszabályi háttér jelentősen befolyásolja az információcsere hatékonyságát, állították a megkérdezettek. Valamennyi megkérdezett egyetértett abban, hogy az irányadó adatvédelmi szabályok jelentősen csökkentik az információcsere hatékonyságát ,, véleményem szerint az adatvédelem inkább a gyanúsitottat védi, mintsem ténylegesen az adatot, lehet nem véletlen, hogy németül a két szó (Datenschutz ${ }^{2}$ és Täterschutz ${ }^{3}$ ) nagyon hasonlit egymásra" (végfelhasználó). A jogszabályi környezet hatására bővebben, a csatornák ismertetésekor térünk ki. A jelenlegi IT rendszer részben ugyan támogatja a határon átnyúló információcserét - derül ki a másodlagos kutatásból -, azonban tekintettel a biztonságos csatorna hiányára az információcserék nagy részében a mai napig

2 Datenschutz: adatvédelem.

3 Täterschutz: az elkövetők védelme. 
a hagyományos adattovábbító eszközöket használják az országok (Saloven et al., 2010, 84.). Ezen probléma kiküszöbölése érdekében, jegyezi meg ugyanezen tanulmány, jelenleg nyolc KSZH teszteli a Biztonságos Információcserét Elősegítő Hálózati Alkalmazást, a SIENA-t. Az Európai Bizottság $(2012,10$. ugyan már 2012-ben hangsúlyozta a rendszer előnyeit és javasolta a tágabb körü alkalmazást, azonban nem találtunk arra vonatkozó információt, hogy a fentebb említett teszten kívül más csatornák, így például a SPOC használná a platformot államközi információcserére. A legtöbb tagállam több, különböző adatbázist üzemeltet, a hozzáférést szabályozó normák nem csak országonként, de egy adott ország rendvédelmi szervez között is eltérnek. A helyzetet tovább bonyolítja, hogy nem mindegyik adatbázis érhető el az adatcserét folytató állomány részére (Saloven et al., 2010, 85.). A szükséges adatbázisok elérhetőségének hiányára panaszkodott a KSZH dolgozó is, ezt a SPOC interjúalany kiegészítette azzal, hogy ,elengedhetetlen a rendszerek átjárhatóságának biztositása, ez jelentösen felgyorsitaná az információcsere folyamatát". Egy, a témában végzett kutatás pozitívumként értékeli, hogy számos tagállam olyan ügykezelő rendszert üzemeltet, ami hozzáférést biztosít a szervezeten belüli valamennyi információhoz, valamint a beépített interfésznek köszönhetően képes azokat továbbítani a megfelelő csatornákon keresztül (Doherty et al., 2015, 48.).

\section{A SPOC müködése}

Az egyablakos rendszer, a SPOC létrehozásnak egyik indoka az előzőekben tárgyalt eltérő szervezeti struktúrák, valamint a különböző nemzeti jogi háttér által okozott nehézségek kiküszöbölése volt. A SPOC, ami általában több, különböző tárgyú információcsere lebonyolítására hivatott funkcionális egységre tagozódik (például Interpol/Europol Nemzeti Iroda, SIRENE, SELEC stb.), a nemzeti rendvédelmi szervezet központi szintjén található, és feljogosított szinte bármely rendészeti jellegü információcsere lebonyolítására. Ez a rendszer egységes és egyszerủ eljárást biztosít, ami elősegíti az információcserét és növeli a hatékonyságot (Európai Unió Tanácsa, 2018, 32.). A Deloitte tanulmány szerint a SPOC az egyik leghatékonyabb csatorna (Saloven et al., 2010,19.) és a kommunikáció könnyebb azon országokkal, amelyek SPOC-t üzemeltetnek. Egy másik tanulmány ugyanakkor rámutat arra is, hogy a koncepció alkalmazása országonként eltérő és a létrehozott struktúra csak részben felel meg az egyablakos rendszer követelményének, emiatt annak hatékonysága és müködése korlátozott (Doherty et al., 2015, 6.). Az interjúalanyok egyetértettek abban, hogy a SPOC az egyedüli csatorna, ami bármely fajta információcserére képes, 
valamint ez a leghatékonyabb csatorna, ha a megkeresés tárgya összetett vagy minősített. Gyakran használják a SPOC-ot olyankor, amikor a kért információ elöreláthatóan felhasználásra kerül a bírói szakaszban, bár ez „gyakran csak a jogszerüség megteremtésére szolgál, mivel az információ többnyire már korábban rendelkezésre áll a KSZH-n, vagy informális csatornákon keresztül végzett adatcsere eredményeként" (végfelhasználó). A SPOC egyik nagy előnye, hogy földrajzi korlátozás nélkül cserél információt nemcsak EU tagállamokkal, de harmadik országokkal is. A megkérdezett SPOC munkatárs szerint az információcsere fele nem szomszédos országokkal történik és a legtöbb megkeresés összetett munkafolyamatot, lépést igényel. A megkeresés a szolgálati út betartásával érkezik a SPOC-hoz email vagy speciálisan erre a célra létrehozott IT alkalmazás igénybevételével. A SPOC másik nagy előnye, hogy ez a csatorna „pontosan ismeri melyik csatorna a leghatékonyabb egy adott megkeresés, illetve egy adott célország tekintetében" (SPOC válaszadó). A csere sebességére illetően mind a KSZH képviselője mind a végfelhasználó egyetértett abban, hogy az információcsere meglehetősen lassú, és ezért a SPOC ,nem alkalmas a mindennapi igények kielégitésére. Elöfordul, hogy olyan megkeresést kapunk, amit több héttel korábban már megküldtek a SPOC-nak de az, válasz nélkül maradt" tette hozzá a KSZH munkatársa.

\section{A KSZH müködése}

A legtöbb SPOC előnyben részesíti a súlyos és szervezett bünözéssel kapcsolatos adatkérést, holott a határon átnyúló bünözés sokszor más, kisebb fajsúlyú büncselekményeket is magába foglal (Saloven et al., 2010, 70.). Ez, valamint a belső határok eltörlése hívta életre a határterületeken egy kevésbé központosított, a rendőri tevékenységet támogató és gyors döntéshozatalt elösegítő közvetlen csatornát, a KSZH-t (Saloven et al., 2010, 70.). A csatorna gyorsaságát megerősítette mind a végfelhasználó, mind a KSZH munkatárs, ez utóbbi elmondta: „A KSZH akár 5-20 perc leforgása alatt is képes a megkeresés teljesitésére, ezért nagyon hatékony, mikor - általános szabályként szomszédos országgal - gyors és egyszerü információcserére van igény." A KSZH adatcseréje általában nem a súlyos büncselekményekkel függ össze, állítja a Rendészeti Információcsere Kézikönyve (a továbbiakban Kézikönyv) (Európai Unió Tanácsa, 2018, 44.), azok inkább kisebb fajsúlyú bünügyekkel, valamint migrációval és a közrenddel kapcsolatosak. Az EU-ban található KSZH-k müködésének jogi hátterét a Schengen egyezmény (Európai Unió, 1985, 44.) teremti meg, mivel azonban a konvenció csak felületes iránymutatásként szolgál, a részletes szabályozást az illetékes országok két-, esetenként többoldalú 
kormányközi megállapodásai nyújtják. Tekintettel arra, hogy nincsen általánosan elfogadott iránymutatás a KSZH-k müködésére vonatkozóan, a hatáskör és illetékesség szabályozása szerteágazó. Az EU szabályozás rugalmatlanná teszi a rendszert, ,, a jogszabályok, kormányközi egyezmények KSZH-ként eltéröek, azok értelmezése pedig még néha egy adott KSZH-n belül is különbözik, ami jelentősen hátráltatja az információcserét” (KSZH válaszadó). A rugalmatlanság feloldható kormányközi megállapodásokkal, ezáltal - állította a KSZH munkatárs - a „Schengen Egyezmény és a svéd kezdeményezés, ami jelentősen bonyolitja munkánkat figyelmen kivül hagyható”. Ezzel ellenkező véleményt formált a SPOC munkatárs, aki szerint a ,jogszabályok biztositják a megfelelö rugalmasságot és ennek köszönhetöen nem akadályozzák az információcserét”. A tisztázatlan jogi háttér teremtette meg a láncmegkeresés intézményét, ami lehetővé teszi, hogy az egymással nem szomszédos, tehát egyezményt sem aláíró országok KSZH-i is információt cserélhessenek egymással, mintegy közvetítőként használva az útba eső KSZH-kat (Doherty et al., 2015, 58.). A Kézikönyv ugyan áttételi kötelezettséget ír elő az illetékes SPOC irányába a SPOC hatáskörébe tartozó megkeresés esetén, ennek ellenére a kutatás szerint nagy számú információcsere történik az illetékes SPOC értesítése és tudta nélkül (Doherty et al., 2015, 51.). A fentieket megerősítette mind a KSZH dolgozó, mind a végfelhasználó. Az illetékesség néhol az egész országot lefedi, néhol csak a határrégióra terjed ki, azonban ,ilyenkor is cserélhet a KSZH országos illetékességgel információt, amennyiben a megkeresés sürgős” - állította a KSZH megkérdezett, majd hozzátette: „,Az illetékesség hiánya áthidalható a lánc-megkereséssel is, ha olyan megkeresést kapok, ami nem kapcsolatos az országommal, vagy nekem van szükségem nem szomszédos országtól adatcserére, lánc-megkereséssel tovább küldöm azt, ezek száma azonban nem éri el az összes ügyszám 10\%-át.”. Ezen esetben tényleges információcsere a közbenső állomások között nem történik, azok csak összekötő funkciót látnak el. A KSZH alkalmanként közremüködő szerepkört is betölt, tájékoztatott a KSZH dolgozó: ,, ha egy KSZH csak a kormányközi megállapodást aláiró országoktól fogad be megkeresést, a kérelem megküldhetö azon KSZH-nak, mely tagja az egyezménynek és elfogad megkeresést külsös országoktól is. Ez a KSZH megküldi a kérelmet a társ KSZH-nak, akinek válasza már a kormányközi megállapodáson alapszik”. Az elmúlt esztendőkben a KSZH elkezdett közvetlenül információt cserélni nem szomszédos országokkal is: „Megjelentek a nem szomszédos országunkkal kapcsolatos megkeresések is, valamint olyanok is melyeket nem szomszédos ország küld meg részünkre követlenül azért, hogy a szomszédos országtól információt szerezzünk. Közvetlen kapcsolat, mikor egy tagállam külföldi rendöre küld közvetlenül nekünk és nem 
a nemzeti KSZH-n keresztül megkeresést, szintén létezik." (KSZH dolgozó.) Ezt támasztotta alá a végfelhasználó is: ,,Van egy listám az EU KSZH-iról, ez alapján küldök nekik közvetlenül megkeresést, néha kapok választ, néha nem, ez nem egységes még egy adott KSZH-n belül sem."

\section{Csatornaválasztás}

A különböző csatornák létezése és a nem egységes jogi szabályozás gyakran zavarodottságot és bizonytalanságot eredményez és megnehezíti a csatornaválasztást (Doherty et al., 2015, 51.). Egyes csatornák használatát részben EU szabályozás, részben nemzetközi szerződés teszi kötelezővé, többségében azonban az igénybeveendő csatornát a nemzeti szabályok határozzák meg (Saloven et al., 2010, 53.). A zavarodottságot csak fokozza, hogy míg a svéd kezdeményezés (Európai Unió Tanácsa, 2006) lehetőséget ad a tagállamoknak bármely csatorna igénybevételére, addig a Schengen Egyezmény (Európai Unió, 1985, cikk 39.) elóírja, hogy információcserére vonatkozó megkeresést a nemzetközi együttmúködésre kijelölt szervnek kell megküldeni, ettől csak abban az esetben lehet eltérni a SPOC egyidejü értesítése mellett -, ha a központi szerv nem képes megfelelő időn belül a válasz megadására. Az évente kiadott és frissített Kézikönyv inkább a svéd kezdeményezést pártolja, mikor a végfelhasználó döntésére bízza a megfelelő és leghatékonyabbnak vélt csatorna használatát (Európai Unió Tanácsa, 2018, 55.). A csatornaválasztást a jogszabályokon kívül befolyásolja még az emberi tényező is, ezen belül a csatorna ismerete, a használatában való jártasság, valamint az irányában fennálló bizalom - derül ki egy korábbi kutatásból (Doherty et al., 2015, 55.). Az interjúalanyok egyetértettek abban, hogy a végfelhasználó relatív nagy szabadsággal bír a csatornaválasztás terén. „A választás többnyire a korábbi személyes tapasztalatoktól függ, esetenként azonban kötelezö egy adott alcsatorna használata (SIRENE, SELEC, Interpol etc.), ilyenkor a SPOC használata kötelezö." (SPOC munkatárs.) A végfelhasználó szerint azonban ,, számos tényezö, úgymint személyes tapasztalat, elérhetö eröforrás, idötényezö, célszerüség stb. gyakran felülírja a jogszabályt”. Az előzőekben ismertetett strukturáltalan csatornaválasztás nehézség elé állítja az információcserében résztvevőket, valamint kockáztatja a folyamat sikerességét és eredményességét - állítják a kutatók (Doherty et al., 2015, 48.) -, továbbá alapot teremt egyszerre több csatorna használatára, ami duplikálást eredményezhet. A Kézikönyv ugyan megengedi a több csatorna egyidejü használatát, azonban erre csak kivételes esetben kerülhet sor, valamennyi megkeresett csatorna egyidejü értesítése mellett (Doherty et al., 2015,6 .). Az esetleges ismétlődések kiszürésében és ezáltal a szükségtelen 
munkateher csökkentésében kiemelt szerep jut a SPOC-nak (Doherty et al., 2015,49 .) és az ügykezelö rendszereknek (Saloven et al., 2010, 99.). A gyors válasz reményében a párhuzamos csatornák használatát legtöbbször a végfelhasználók kezdeményezik, ez azonban, ha „egységes ügykezelöi rendszer müködik azonnal kiszúrható" (KSZH dolgozó). Abban mindhárom válaszadó egyetértett, hogy az információcserét hátráltató többletmunka és átfedés csak akkor keletkezik, ha a kérelmező nem jelölte meg megkeresésében a csatornák párhuzamos használatát és az észrevétlenül marad, ezáltal több csatorna dolgozik egyszerre ugyanazon a megkeresésen. Itt kell megemlítenünk az informális információcsere - amikor a kérelmező személyes kapcsolati hálóját használja fel annak érdekében, hogy mihamarabb választ kapjon megkeresésére - térnyerését. Az ilyen kérelmeket általában formális megkeresés is követi annak érdekében, hogy a megszerzett információ felhasználható legyen a büntetőeljárás során. Természetéből fakadóan nehéz megbecsülni ezen csatorna használatának gyakoriságát (Saloven et al., 2010, 99.), azonban egy friss kutatás szerint (Kemény, 2019) az információcserével foglalkozók jelentős többsége használta már az informális csatornát. Az informális csatornák (zárt WhatsApp, Facebook stb. csoportok, telefonhívások) használata jelentősen megnőtt, állította a végfelhasználó, mivel ,, a hivatalos csatornák egyszerüen nem képesek rövid időn belül válaszolni, ezért alapvetöen kettö választásunk van: használni vagy nem használni az informális csatornákat, ez utóbbi esetben azonban megengedjük például belépni az EU területére azt, akinek gyanúnk szerint úti okmánya, vagy az abban található bélyegzö lenyomat hamis, illetve hagyjuk az EU területét el hagyni olyan jármüveknek mely elképzelhetö, hogy büncselekmény tárgyát képezi, mindez pedig jelentös biztonsági kockázatot jelent". A csatornát akkor használják, mikor egy körülmény gyanús, de a rendelkezésre álló adatok nem elegendőek a megalapozott gyanú megállapítására és a döntéshozatalra az intézkedő rendőrnek mindössze néhány perc áll rendelkezésre. Az adatcserét, amennyiben a gyanút megerősítő információ érkezik és további intézkedés szükséges, egy hivatalos megkeresés is követi. A végfelhasználó szerint a csatorna használatának alapvető feltétele a kölcsönösség és a bizalom. Az informális csatornát nem használják a KSZH és a SPOC dolgozói, derült ki az interjúkból.

\section{Befejezés}

A kutatás bebizonyította, hogy a határon átnyúló rendészeti információcserére is érvényes a Yang és Maxwell által felállított környezetelmélet. Ennek 
értelmében az információcsere hatékonyságát a három - a szervezeti, jogi és technológiai - környezet befolyásolja. Megállapíthatjuk, hogy a szervezeti környezeten belül az erősen centralizált, bürokratikus szervezeti struktúra, az autoriter vezetési stílus, a feladatra szabott ösztönzők, a bizalom és reciprocitás hiánya, valamint az eltérő szervezeti kultúra a legmeghatározóbb akadályozó tényezők az információcsere során. A jogi környezet esetében kijelenthető, hogy az eltérő nemzeti elöírások, adatvédelmi szabályok és az EU instrumentumok nem egységes értelmezése a legjelentősebb hátráltató és lassító tényező. A korszerütlen IT környezet, az átjárhatóság, a kompatibilitás, a megfelelő ügykezelő rendszer és a biztonságos csatorna hiánya, valamint az elkülönült adatbázisok burjánzása lassítja az információcserét, rontja annak hatékonyságát. A kutatás feltárta azt is, hogy az információcserére használt csatorna kiválasztása is függ az országok rendvédelmi szerveinek szerkezetétől, az elérhető IT rendszerektől és jogszabályoktól. Mivel az irányadó normák és iránymutatások ellentmondásosak, értelmezésük nemcsak az EU-n, de egy országon, valamint néha egy adott szolgálati helyen belül is eltérő, ezért a csatornaválasztást nagy mértékben befolyásolja a kérelmező személyes tapasztalata és tájékozottsága, mely gyakran a jogszabályi rendelkezés felülírását eredményezi. A fentiekben felsorolt hátráltató tényezők jelentősen lelassíthatják az információcserét, ami egyrészt hozzájárult az informális csatornák térnyeréséhez, másrészt pedig a szükséges rendőri intézkedés elmulasztását eredményezi, komoly biztonsági kockázatot okozva ezáltal mind a tagállamoknak, mind az EU-nak. Az információcsere hatékonyságának növelése érdekében az egyik legfontosabb teendő az egységes jogi háttér megteremtése, valamint a KSZH-k bevonása a nem szomszédos országokkal történő adatcserébe, az illetékességi szabályok EU szinten történő módosításával. A sebesség és ezáltal a hatékonyság növelése érdekében valamennyi csatorna és végfelhasználó számára biztosítani kell a munka ellátásához szükséges adatbázisokhoz való közvetlen hozzáférést, az adatbázisok átjárhatóságát, valamint az egységes üzenetformátum EU szinten történő bevezetését. A SIENA teljeskörü igénybevétele tagállamok közötti információcserére, valamint az egységes ügykezelö rendszer bevezetése szintén elengedhetetlen egy hatékony csatorna működéséhez. Biztonságos mobil applikáció használata, mely megteremti a végfelhasználó részére a KSZH-val és SPOC-al való közvetlen kapcsolatfelvétel lehetőségét, gyorsítaná az információcserét, valamint csökkentené az informális csatornák igénybevételét. Végül kiemelt figyelmet kell fektetni a vezetési stílusban rejlő lehetőségekre a parancsnokok képzésével, a munkaspecifikus ösztönzők bevezetésével, valamint a visszacsatolás rendszerének intézményesítésével. 


\section{Felhasznált irodalom}

Bayley, D. H. (1990): Patterns of Policing: A Comparative International Analysis. Rutgers University Press.

Bock, G.-W., Zmud, R. W., Kim, Y.-G. \& Lee, J.-N. (2005): Behavioral Intention Formation in Knowledge Sharing: Examining the Roles of Extrinsic Motivators, Social-Psychological Factors, and Organizational Climate. MIS Quarterly, 29(1), 87-111. https://doi.org/10.2307/25148669

Bryman, A. (2012): Social research methods. Oxford University Press. https://doi.org/10.1017/ CBO9781107415324.004

Bstieler, L. (2006): Trust formation in collaborative new product development. Journal of Product Innovation Management, 23(1), 56-72. https://doi.org/10.1111/j.1540-5885.2005.00181.x

Cater, B. (2008): The importance of social bonds for Communication and trust in marketing relationships in professional services. Management, 13(1), 1-15.

Chau, M., Zeng, D. D., Atabakhsh, H. \& Chen, H. (2001): Building an Infrastructure for Law Enforcement Information Sharing and Collaboration: Design Issues and Challenges. Proceedings of The National Conference for Digital Government Research. Los Angeles, California, May 21-23.

Constant, D., Kiesler, S. \& Sproull, L. (1994): What's Mine Is Ours, or Is It? A Study of Attitudes about Information Sharing. Information Systems Research, 5(4), 400-421.

Doherty, R., Vandresse, B., Kamarás, É., Siede, A., Segerberg, J., Hert, P. \& Mitsilegas, V. (2015): Study on the implementation of the European Information Exchange Model (EIXM) for strengthening law enforcement cooperation. Deloite, 108.

Európai Bizottság (2004): A Bizottság közleménye az Európai Parlamentnek és a tanácsnak az Európai Unión belüli rendörségi és vámügyi együttmüködés megerösitéséröl I. Jelentés az amszterdami szerzödés hatálybalépése óta elért eredményekröl II. Fejlesztési javaslatok (COM/2004/0376).

Európai Bizottság (2012): A Bizottság Közleménye az Európai Parlamentnek, a Tanácsnak Az EU-n belüli bünüldözési együttmüködés erösitése: az európai információcsere-modell (COM/2012/0735 final).

Európai Unió (1985): Egyezmény a Benelux Gazdasági Unió államai, a Németországi Szövetségi Köztársaság és a Francia Köztársaság kormányai között a közös határaikon történö ellenörzések fokozatos megszüntetéséről szóló, 1985. június 14-i Schengeni Megállapodás végrehajtásáról. Európai Unió Tanácsa (2006): A Tanács 2006/960/IB Kerethatározata az Európai Unió tagállamainak bünüldöző hatóságai közötti, információ és bünüldözési operatív információcseréjének leegyszerüsítéséről (2006/960/JHA). Az Európai Unió Hivatalos Lapja.

Európai Unió Tanácsa (2018): Rendészeti Információcsere Útmutatója (6727/18).

Gil-García, J. R. \& Pardo, T. A. (2005): E-government success factors: Mapping practical tools to theoretical foundations. Government Information Quarterly, 22(2), 187-216. https://doi. org/10.1016/j.giq.2005.02.001 
Goldenberg, I. \& Dean, W. H. (2017): Enablers and Barriers to Information sharing in Military and Security Operations: Lessons Learned. In Goldenberg, I., Soeters, J. \& Dean, W. (eds.): Information sharing in military operations, 251-267. Springer

Hufnagel, S. (2016): Policing cooperation across borders. Routledge.

Kemény, G. (2019): Fifteen minutes to decide:The efficiency of cross-border information exchange conducted by the Single Point of Contact and the Police and Customs Cooperation Centre. Frontex

Keohane, R. O. (1986): Reciprocity in international relations. International Organization, 40(1), $1-27$.

Kim, S. \& Lee, H. (2006). The Impact of Organizational Context and Information Technology on Employee Knowledge-Sharing Capabilities. Public Administration Review, 66(3), 370-385. https://doi.org/10.1111/j.1540-6210.2006.00595.x

Kovács I. (2015): „Olajozás”, szervezett bünözés és prostitúció a 90-es években Magyarországon. Nemzetbiztonsági Szemle, 3(1), 114-145.

Lane, C. \& Bachmann, R. (1996): The Social Constitution of Trust: Supplier Relations in Britain and Germany. Organization Studies, 17(3), 365-395. https://doi.org/10.1177/017084069601700302 Mausolf, A. (2010): Keeping Up Appearances: Collaboration and Coordination in the Fight against Organized Crime and Terrorism. Unpublished Master's Thesis, University of Leiden

Resteigne, D. \& Bogaert, S. Van den. (2017): Information Sharing in Contemporary Operations: The Strength of SOF Ties. In Goldenberg, I., Soeters, J. \& Dean, W. (eds.): Information sharing in military operations, 51-66. Springer https://doi.org/10.1007/978-3-319-42819-2_4

Saloven, M., Grant, E., Hanel, P., Makai, V., Brent Hansen, K., Belevicius, L. \& Pohnitzer, A. (2010): Study on the status of information exchange amongst law enforcement authorities in the context of existing EU instruments. https:/ec.europa.eu/home-affairs/sites/homeaffairs/ files/doc_centre/police/docs/icmpd_study_lea_infoex.pdf

Saunders, M., Lewis, P. \& Thornhill, A. (2008): Research Methods for Business Students. Pearson Education Limited.

Styczyńska, I. \& Beaumont, E.-Z. (2017): Easing legal and administrative obstacles in EU border regions. Luxembourg: Publication Office of the European Union. https://doi.org/10.2776/251376

Wheatley, M. J. (2006): Leadership and the New Science: Discovering Order in a Chaotic World. Berrett-Koehler Publishers

Willem, A. \& Buelens, M. (2007): Knowledge sharing in public sector organizations: The effect of organizational characteristics on interdepartmental knowledge sharing. Journal of Public Administration Research and Theory, 17(4), 581-606.

Yang, T.-M. \& Maxwell, T. A. (2011): Information-sharing in public organizations: A literature review of interpersonal, intra-organizational and inter-organizational success factors. Government Information Quarterly, 28(2), 164-175. https://doi.org/10.1016/j.giq.2010.06.008

Yin, R. K. (2014): Case Study Research Design and Methods (5th ed.). Thousand Oaks, Sage. 
Zhang, J. \& Dawes, S. S. (2006): Expectations and Perceptions of Benefits, Barriers, and Success in Public Sector Knowledge Networks. Public Performance és Management Review, 29(4), 433-466.

Zhang, J., Sharon, S. D. \& Sarkis, J. (2005): Exploring stakeholders' expectations of the benefits and barriers of e-government knowledge sharing. Journal of Enterprise Information Management, 18(5), 548-567. https://doi.org/10.1108/17410390510624007

\section{A cikk APA szabály szerinti hivatkozása}

Kemény G. (2020): Az Egyedüli Kapcsolattartási Pont és a Közös Kapcsolattartási Szolgálati Hely által foganatosított információcserét befolyásoló környezeti tényezők. Belügyi Szemle, 69(1), 107-122. https://doi.org/10.38146/BSZ.2021.1.5 